\title{
Forkhead Box Protein L2
}

National Cancer Institute

\section{Source}

National Cancer Institute. Forkhead Box Protein L2. NCI Thesaurus. Code C75474.

Forkhead box protein L2 (376 aa, $\sim 39 \mathrm{kDa}$ ) is encoded by the human FOXL2 gene. This protein plays a role in both the development and functioning of the ovary. 